Research paper

\title{
Daylight Saving Time policy and energy consumption
}

\author{
Sinan Küfeoğlu ${ }^{a}$,b,*, Şahincan Üçler ${ }^{c}$, Furkan Eskicioğlu ${ }^{c}$, E. Büşra Öztürk ${ }^{\mathrm{d}}$, Hao Chen ${ }^{e}$ \\ ${ }^{a}$ Department of Engineering, University of Cambridge, Cambridge, United Kingdom \\ ${ }^{\mathrm{b}}$ Department of Energy Systems Engineering, Bahçeşehir University, Istanbul, Turkey \\ ${ }^{c}$ Department of Mathematics Engineering, Istanbul Technical University, Istanbul, Turkey \\ d Department of Mathematics, Bilkent University, Ankara, Turkey \\ e School of Applied Economics, Renmin University of China, Beijing, China
}

\section{A R T I C L E I N F O}

Article history:

Received 9 May 2021

Received in revised form 17 July 2021

Accepted 3 August 2021

Available online 19 August 2021

\section{Keywords:}

Daylight Saving Time

Energy saving

Load shift

Electricity consumption

Summer time zone

Winter time zone

\begin{abstract}
A B S T R A C T
Daylight Saving Time is argued to be effective in saving energy. Turkey is one of the few countries that annulled the clock changes and remained in the summertime zone in 2016. Therefore, the country provides a unique natural experiment to test and confirm this policy change. This paper studies the impact of clock changes on electric energy consumption and load shift. We use historical electrical energy consumption, electricity prices, and relevant atmospheric essential climate variables data in Turkey between 2012-2020. We adopt Multiple Linear Regression, Difference in Differences and Interrupted Time Series methodologies to analyse the historical data. This paper shows that the Daylight Saving Time policy does not lead to a measurable amount of electrical energy savings. Furthermore, it does not cause a noticeable continuous daily load shift throughout the year. We also claim that our findings should apply to countries such as the United States, India, Japan, Australia or China, and continents of Africa and South America, whose latitudes are between $42.0^{\circ}$ north and south of the equator.
\end{abstract}

(C) 2021 The Authors. Published by Elsevier Ltd. This is an open access article under the CC BY-NC-ND license (http://creativecommons.org/licenses/by-nc-nd/4.0/).

\section{Introduction}

Daylight Saving Time (DST) aims to take advantage of daylight by shifting an hour forward in the spring and backwards in the fall. Benjamin Franklin firstly introduced the concept of Daylight Saving Time in 1784 (Prerau, 2005). Franklin's primary objective of Daylight Saving Time was energy conservation since extending the sunlight hours in a day diminishes artificial light usage (Kotchen and Grant, 2011). However, DST had become a considerable interest to a broader audience be adopted more than a century later. During World War I, the first implementation of DST was done in 1916 by German Federal Council to increase war effort by decreasing the demand for coal for electrical lightning (Prerau, 2005). In those times, Frankfurter Zeitung enthusiastically noted the benefit of DST for Germany that the policy lengthened the amount of daylight by about $150 \mathrm{~h}$ (Prerau, 2005). Britain, France, the United States, and most other countries, including Turkey, had adopted DST for wartime purposes. Even though DST enabled countries to conserve energy during wartime, the continuation of the implementation of this policy had been questioned after the war with justification for diminishing productiveness of farmers (Prerau, 2005). The policy has

\footnotetext{
* Corresponding author at: Department of Engineering, University of Cambridge, Cambridge, United Kingdom.

E-mail address: sk959@cam.ac.uk (S. Küfeoğlu).
}

been found controversial for many other reasons. One of the main questions is whether it caused more electricity consumption or saved more energy considering other economic activities linked to electricity other than just lighting. Some countries ceased the policy's implementation and reintroduced it again, and some of them ceased the application permanently.

In the literature, daylight saving time was addressed by numerous studies. The study Kotchen and Grant (2011) investigate the effects of daylight-saving time, and they conducted a Difference in Difference (DID) methodology. The study Kudela et al. (2020) conducted research about daylight saving time in Slovakia with hypothetical scenarios, and they also used DID method. They suggest that the DST policy decrease $1 \%$ of annual electricity consumption. The study from Australia (Kellogg and Wolff, 2008) examined how the daylight-saving time policy influenced electricity demand. The difference in differences method was used with detailed panelled data. They indicated no effect of the DST policy on electricity consumption by showing a decrease in energy consumption in the evening whilst a demand increase in the morning compensates for it.

The research was not only conducted for measuring the energy conservation on daylight saving time. Studies inspect the effects of the biannual clock change on human behaviour, the life of satisfaction and welfare effects. The work Kuehnle and Wunder (2016) presents a comprehensive study that measures the welfare effects of the time change policy on people in the 
UK and Germany. Also, they used a regression discontinuity design to estimate the impact of the daylight-saving policy on life satisfaction. This study showed that the workers in the UK and Germany considerably affected by the transition to DST; this effect revealed in the society as an efficiency loss. The reference Sexton and Beatty (2014) shows the change in individuals' time usage behaviours with a shift in the daylight.

Turkey was one of the countries that stopped implementing DST between 1923 and 1940 (Karasu, 2010). After a few periods that the policy was suspended again, the DST policy was abolished entirely in 2016, and Turkey remained permanently in the summertime zone. The Official Gazette of Ministers, dated September 8, 2016, published the decree of No. 2016/9154 of Cabinet enacted summertime to become the country's permanent status (Erdogan et al., 2016). In 1991 China, in 2009, Pakistan, in 2010, Russia, in 2015 Azerbaijan and 2019 Brazil abolished the DST policy (The World Clock - Worldwide, 2021). Moreover, the European Parliament voted to repeal the practice of DST in 2021. The member states will choose to remain either in the summer or in the wintertime permanently (State of the Union, 2018). However, there is still an ambiguity in many places for which time zone to choose. Table 1 shows a summary of the existing literature and presents the contradicting findings of the studies worldwide.

The impact of DST on energy consumption is still a debatable topic. Even though this policy's beginning was driven by energysaving purposes, we cannot find concrete evidence of whether or not this is the case. In the literature, there are controversial papers that propose just the opposite. For instance, whilst studies Havranek et al. (2018) suggest that the DST policy has no effect on energy consumption, Mirza and Bergland (2011) claims the country would save $1 \%$ of electricity consumption (Krarti and Hajiah, 2011) argues that the DST policy causes an increase in energy consumption. These three different results showed us, DST policy is complicated and hard to clarify the proper solution.

This paper presents an analysis to investigate the Daylight Saving Time policy's impact by adopting two widely acknowledged methodologies, namely Multi Linear Regression (MLR), Interrupted Time Series (ITS) and Difference-in-Differences (DID) approaches. Since Turkey abolished this policy in 2016, we will be using actual historical data rather than simulations or hypothetical scenarios. This paper takes Turkey as a case study and examines the electricity consumption, price, and relevant atmospheric essential climate variables datasets from 2012 to 2020. For the rest of the paper, the term energy will solely imply electrical energy, and hence the paper only investigates the impact of DST on electrical energy consumption.

\section{Factors affecting electricity consumption}

Besides the utilised atmospheric essential climate variables data: temperature, wind, humidity, barometer, and visibility, in this article, to determine the influence of DST on electricity consumption, numerous important factors should also be considered. Factors that affect electricity consumption can be grouped under the following headings; social, economic, socio-economic, socio-demographic, behavioural, the character of dwelling, and appliances variables. A detailed list of these factors is given in Table 2.

Table 2 lists some of the parameters that affect electricity consumption. Probably there are many more factors than we reviewed and mentioned here. It is almost impossible to claim a precise list of impacts and tell these are the only parameters that affect electricity consumption in the world. However, the lack of available data on these factors causes it to be uncertain if DST is one of the main determinants of electricity consumption. Daylight
Saving Time policy is about harnessing the daylight as much as possible, and hence the related parameters are the atmospheric climate variables. Furthermore, energy prices are strong market signals for energy consumption, and some of the DST literature take energy prices as input parameters for DST studies. Therefore, to measure DST's impact on electricity consumption, we only used atmospheric climate variables and electricity prices in this paper.

\section{Methodology}

In the literature, there are three prominent types of methodologies used to measure DST policy's effect on the energy conversation. We studied these methods and highlighted the disadvantages and advantages in Table 3.

In our study, the Turkish Transmission System Operator's (TEIASS) electricity consumption data was used for the analysis (TEIASS, 2021). The weather data were taken from the Turkish State Meteorological Service (MGM, 2021).

\subsection{Multiple linear regression analysis}

We aim to measure the impact of DST on the hourly electricity consumption data. We constructed a multiple regression model whose dependent variable is the hourly electricity consumption, and the independent variables are the atmospheric essential climate parameters. Eight independent variables were defined for our model. There are dozens, maybe hundreds, of parameters that have an impact on the consumption of electricity. It is hard to consider all these parameters from the real world due to a lack of data and hard to reach specific data.

Harnessing daylight is prominent, especially in lighting and heating. Therefore, we narrowed down our independent variables, or the parameters of relevance, to essential climate variables or merely weather data such as temperature, wind speed, humidity, weather condition, and visibility. Due to currency fluctuations and high inflation, electricity prices in Turkey are updated often and regularly. Also, since we use historical datasets, we took into account the electricity prices because the consumption of a product or a commodity is directly affected by its price in the long run. We used temperature as an independent variable because people might use air conditioners and heaters to make sudden air temperature changes. Therefore, it might affect the consumption of electricity with the usage of heaters or air conditioners. The humidity change could also affect the air conditioners' electricity consumption due to the condensation of the water vapour in the air. Especially in the summer, while the air conditioner cools indoors, because of the water vapour's condensation, consumption of the electricity will increase (Guan et al., 2017). When the weather is cloudy or rainy, we need more electric energy to illuminate houses, streets, and cities. Weather condition is a categorical variable, and it consists of 71 subcategories which are shown in Table 4.

We fed these 71 subcategories in our regression model as different weather parameters. In addition to weather conditions, we propose several other variables related to daylight saving. One of them is the intersection factor. We add the intersection variable that measures the intersection of work hours and the day's sunlight duration. With the intersection variable, we estimate what percentage of the daylight is being made use of workers. For example, let us assume that the working hours are 8 am and 5 $\mathrm{pm}$, and the sunrise is at 6:30 am, and the sunset is at 6:30 pm. In this case, all working hours lie in between sunlight duration and hence the intersection factor is 1.0. The other parameter is the Daylight Saving Time (DST) variable. DST variable is a categorical variable, and it represents whether the country is in the summer 
Table 1

Existing literature for the impact of DST on energy consumption.

\begin{tabular}{|c|c|c|c|c|c|}
\hline Reference & Year & Country & Method & $\begin{array}{l}\text { DST impact of Energy } \\
\text { Consumption }\end{array}$ & Remarks \\
\hline Hill et al. (2010) & 2010 & UK & $\begin{array}{l}\text { Literature review } \\
\text { (Historical data) }\end{array}$ & Review & $\begin{array}{l}\text { This paper conducts a } \\
\text { literature review of the effect } \\
\text { of DST on energy consumption. }\end{array}$ \\
\hline Rock (1997) & 1997 & US & $\begin{array}{l}\text { Simulation with } 224 \\
\text { residential loads }\end{array}$ & $\begin{array}{l}\text { energy consumption } \\
\text { increases }\end{array}$ & $\begin{array}{l}\text { The study focuses on } \\
\text { residential HVAC and lighting } \\
\text { for typical US houses. }\end{array}$ \\
\hline Awad Momani et al. (2009) & 2009 & Jordan & $\begin{array}{l}\text { Comparison of the } \\
\text { average daily load curves } \\
\text { and Survey study } \\
\text { (Historical Data) }\end{array}$ & $\begin{array}{l}\text { energy consumption } \\
\text { increases between } \\
0.5 \%-1.7 \%\end{array}$ & $\begin{array}{l}\text { This paper focuses on the } \\
\text { impact of daylight saving time } \\
\text { on Jordan's energy } \\
\text { consumption. }\end{array}$ \\
\hline Krarti and Hajiah (2011) & 2011 & Kuwait & Simulation & $\begin{array}{l}\text { energy consumption } \\
\text { increases by } 0.07 \%\end{array}$ & $\begin{array}{l}\text { This paper examines the DST } \\
\text { effect on the building sector's } \\
\text { energy consumption. }\end{array}$ \\
\hline Kotchen and Grant (2011) & 2011 & US & $\begin{array}{l}\text { Difference in Differences } \\
\text { and Regression Model } \\
\text { (Historical Data) }\end{array}$ & $\begin{array}{l}\text { energy consumption } \\
\text { increases }\end{array}$ & $\begin{array}{l}\text { This paper conducted a natural } \\
\text { experiment in Indiana for } \\
\text { estimating DST effects on } \\
\text { energy consumption. }\end{array}$ \\
\hline Verdejo et al. (2016) & 2015 & Chile & $\begin{array}{l}\text { Heuristic Approach and } \\
\text { econometric model } \\
\text { (Historical Data) }\end{array}$ & $\begin{array}{l}\text { energy consumption } \\
\text { increases by } 3.18 \%\end{array}$ & $\begin{array}{l}\text { This paper focuses on the } \\
\text { impact of daylight saving time } \\
\text { on the Chilean residential } \\
\text { consumption }\end{array}$ \\
\hline Hancevic and Margulis (2016) & 2019 & Argentina & $\begin{array}{l}\text { Difference in difference } \\
\text { (Historical Data) }\end{array}$ & $\begin{array}{l}\text { energy consumption } \\
\text { increases between } 0.4 \% \\
\text { and } 0.6 \%\end{array}$ & $\begin{array}{l}\text { They used a natural } \\
\text { experiment from Argentina to } \\
\text { provide empirical estimates of } \\
\text { DST's effects. }\end{array}$ \\
\hline Bellia et al. (2020) & 2020 & Europe & $\begin{array}{l}\text { Simulation with } 11 \\
\text { different cities }\end{array}$ & $\begin{array}{l}\text { energy consumption } \\
\text { increases }\end{array}$ & $\begin{array}{l}\text { The study focuses on DST on } \\
\text { energy consumption for } \\
\text { illumination at the office. }\end{array}$ \\
\hline Belzer et al. (2008) & 2008 & US & $\begin{array}{l}\text { Four methods were } \\
\text { conducted (Regression } \\
\text { model, Heuristic, } \\
\text { Comparison of } \\
\text { differences, before and } \\
\text { after analysis) (Historical } \\
\text { Data) }\end{array}$ & $\begin{array}{l}\text { energy consumption } \\
\text { decreases }\end{array}$ & $\begin{array}{l}\text { This report provides a } \\
\text { comprehensive study with the } \\
\text { result, data, and analytical } \\
\text { methods used in the DOE } \\
\text { Report to Congress }\end{array}$ \\
\hline Mirza and Bergland (2011) & 2011 & Norway \& Sweden & $\begin{array}{l}\text { Difference in difference } \\
\text { (Historical data) }\end{array}$ & $\begin{array}{l}\text { energy consumption } \\
\text { decreases at least } 1 \% \text {. }\end{array}$ & $\begin{array}{l}\text { In this paper, DST effect was } \\
\text { examined on the energy } \\
\text { consumption in Norway and } \\
\text { Sweden }\end{array}$ \\
\hline López (2020) & 2020 & Spain & $\begin{array}{l}\text { Simulation and } \\
\text { mathematical model }\end{array}$ & $\begin{array}{l}\text { energy consumption } \\
\text { decreases between } \\
0.22 \%-0.34 \%\end{array}$ & $\begin{array}{l}\text { This paper examines the } \\
\text { variations of sunrise and sunset } \\
\text { times' effect on the electricity } \\
\text { demand daily profile. }\end{array}$ \\
\hline Kellogg and Wolff (2008) & 2008 & Australia & $\begin{array}{l}\text { Simulation and } \\
\text { Difference-in-difference }\end{array}$ & $\begin{array}{l}\text { No effect on energy } \\
\text { consumption }\end{array}$ & $\begin{array}{l}\text { This paper focuses on the } \\
\text { daylight saving time extension } \\
\text { on energy consumption in } \\
\text { Australia }\end{array}$ \\
\hline Havranek et al. (2018) & 2018 & Czech Republic & $\begin{array}{l}\text { Literature review } \\
\text { (Simulation and } \\
\text { Historical data) }\end{array}$ & No evidence found & $\begin{array}{l}\text { They examined } 44 \text { studies that } \\
\text { are research articles, } \\
\text { government papers, and energy } \\
\text { company reports. }\end{array}$ \\
\hline
\end{tabular}

or winter time zones. Visibility is another variable that we added to the model to measure its effect primarily on illumination.

Our MLR model for the measurement of DST on electricity consumption is shown in Eq. (1).

$$
\begin{aligned}
y=a+ & \beta_{\text {Temp }} X_{1}+\beta_{\text {wind }} X_{2}+\beta_{\text {Electricity price }} X_{3} \\
& +\beta_{\text {Intersection }} X_{4}+\beta_{\text {Humidity }} X_{5} \\
& +\beta_{\text {Weather }} X_{6}+\beta_{\text {Visibility }} X_{7}+\beta_{\text {DST }} X_{8}
\end{aligned}
$$

where,

$\mathrm{y}$ : dependent variable, which represents the electricity consumption.

a: the constant (y-intercept)

$\aleph_{\text {Temp }}$ : the coefficient of temperature and $X_{1}$ : the independent variable temperature,

$\beta_{\text {wind }}$ : the coefficient of the wind and $X_{2}$ : the independent variable wind,

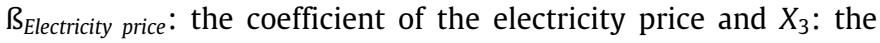
independent electricity price variable wind, $\aleph_{\text {Intersection: }}$ the coefficient of the intersection factor and $X_{4}$ : the independent intersection variable,

$\beta_{\text {Humidity }}$ refers to the coefficient of the humidity and $X_{5}$ : independent humidity variable,

$\beta_{\text {Weather }}$ : the coefficient of the weather and $X_{6}$ : independent weather variable,

$\beta_{V i s i b i l i t y}$ : the coefficient of the visibility and $X_{7}$ : independent visibility variable,

$\beta_{D S T}$ : the coefficient of the DST and $X_{8}$ : independent DST variable.

\subsection{Interrupted Time Series Analysis}

A continuous sequence of observations over time is called a Time Series. Interrupted Time Series (ITS) analysis measures the interventions within the time series. ITS analysis reveals the changing trend in outcome with specific intervention in a time series. Changing the time zone in 2016 is an intervention to the DTS policy in Turkey. Using the ITS method, we wanted to show the impact of this decision on electricity consumption. Therefore, 
Table 2

Factors affect the consumption of electricity.

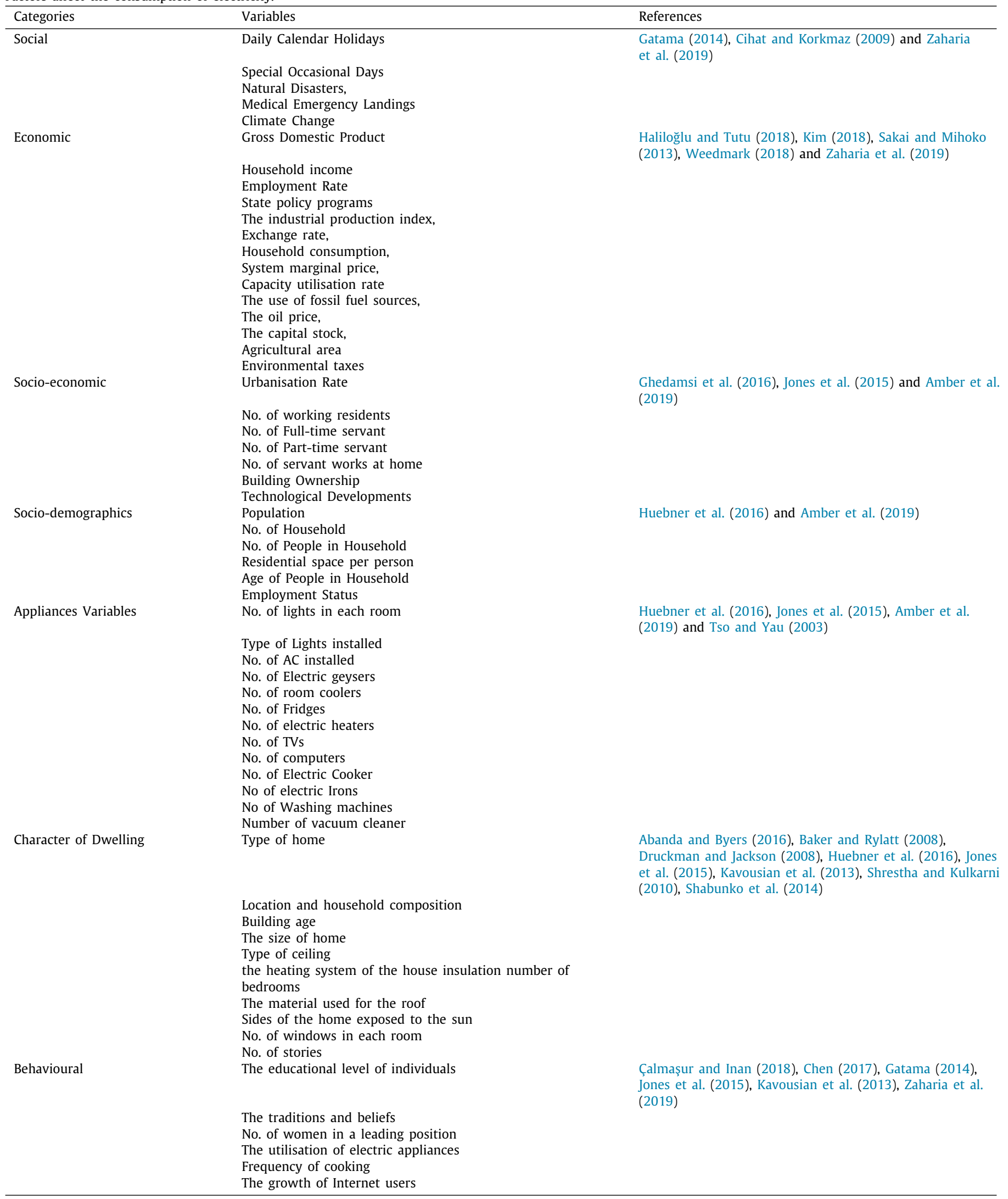

according to ITS methodology, we defined the required three

variables. These are listed as: i. Time elapsed: This variable measures the elapsed time since the start of the study by a unit of frequency of the observations; in our case, it is hourly data. 
Table 3

Methodologies to be applied in DST research.

\begin{tabular}{|c|c|c|c|}
\hline Model & Description & Advantages & Disadvantages \\
\hline $\begin{array}{l}\text { Multiple Linear } \\
\text { Regression } \\
\text { (Weedmark, 2018) }\end{array}$ & $\begin{array}{l}\text { A statistical method that estimates } \\
\text { the relationship between continuous } \\
\text { quantitative variables. }\end{array}$ & $\begin{array}{l}\text { - It helps determine which factors } \\
\text { matter most, which it can ignore } \\
\text { through criterion value. } \\
\text { - It gives information about the } \\
\text { relevance of features } \\
\text { - It uses data very efficiently and can } \\
\text { make useful predictions. }\end{array}$ & $\begin{array}{l}\text { - It assumes a straight-line relationship between the } \\
\text { dependent and independent variables, which is } \\
\text { incorrect many times. } \\
\text { - It is not able to capture the information in the data. } \\
\text { - It does not allow the introduction of all available } \\
\text { variables since their effects would cancel each other } \\
\text { out because of the lack of independence }\end{array}$ \\
\hline $\begin{array}{l}\text { Difference in Differences } \\
\text { (DID) } \\
\text { (Priva and Sanker, 2019; } \\
\text { Zhou et al., 2016) }\end{array}$ & $\begin{array}{l}\text { A design that examines the } \\
\text { comparison of differences in } \\
\text { outcomes of a treated time series } \\
\text { with an untreated series by referring } \\
\text { controlled before-and-after an } \\
\text { intervention. }\end{array}$ & $\begin{array}{l}\text { - The method is intuitive and fairly } \\
\text { flexible } \\
\text { - It allows estimating the treatment } \\
\text { effect. } \\
\text { - It demonstrates a causal impact } \\
\text { from observational data if the } \\
\text { assumptions of design are consistent. } \\
\text { - There is no need to assume that all } \\
\text { differences between before and after } \\
\text { intervention are measured. }\end{array}$ & $\begin{array}{l}\text { - The only difference in DID should be exposure to } \\
\text { intervention which may not be possible for time } \\
\text { series. } \\
\text { - The analysis may be biased if the trends between } \\
\text { the two groups are significantly different, } \\
\text { - DID does not explain unobservable variables that } \\
\text { are not fixed over time }\end{array}$ \\
\hline $\begin{array}{l}\text { Interrupted Time Series } \\
\text { (ITS) } \\
\text { (Lopez Bernal et al., } \\
\text { 2017; Ewusie et al., } \\
\text { 2020) }\end{array}$ & $\begin{array}{l}\text { A methodology which uses to } \\
\text { evaluate multiple consecutive } \\
\text { pre-and post-intervention } \\
\text { observations in a single population } \\
\text { and incorporates time by comparing } \\
\text { slopes of trend lines before and after } \\
\text { the intervention }\end{array}$ & $\begin{array}{l}\text { - This method uses standard } \\
\text { regression techniques and hence easy } \\
\text { to implement. } \\
\text { - It can determine whether the } \\
\text { alteration is permanent or temporary. } \\
\text { - It represents circumstances in real } \\
\text { life and is easy to recreate in } \\
\text { practice. } \\
\text { - It allows both observation of } \\
\text { change and the nature and timing of } \\
\text { occurrence. } \\
\text { - ITS can detect intermittent changes. }\end{array}$ & $\begin{array}{l}\text { - There is an issue with determining whether a } \\
\text { change noted is due to the intervention or other } \\
\text { factors. } \\
\text { - It is incapable of assessing the assumption of } \\
\text { comparability, and thus, overall results might be } \\
\text { suboptimal if pre-and post-intervention are not } \\
\text { comparable. } \\
\text { - It is unable to control for possible } \\
\text { contemporaneous and imperative for future research }\end{array}$ \\
\hline
\end{tabular}

Table 4

Weather condition subcategories.

\begin{tabular}{lll}
\hline Weather Conditions & & \\
\hline Passing clouds. & Clear. & Light fog. \\
Partly cloudy. & Partly sunny. & Drizzle. Broken clouds. \\
Snow showers. Fog. & Rain showers. Passing clouds. & Light rain. Passing clouds. \\
Snow flurries. Broken clouds. & Sprinkles. Partly sunny. & Light rain. Partly cloudy. \\
Snow showers. Partly sunny. & Sprinkles. Fog. & Light rain. Broken clouds. \\
Broken clouds. & Rain showers. Partly sunny. & Light rain. Partly sunny. \\
Snow flurries. Fog. & Cool. & Light rain. More clouds than the sun. \\
Snow flurries. Partly sunny. & Thunderstorms. Passing clouds. & Light rain. Mostly cloudy. \\
Snow flurries. Passing clouds. & Thunderstorms. Partly cloudy. & Rain. Mostly cloudy. \\
Snow flurries. Partly cloudy. & Rain showers. Broken clouds. & Rain. Partly cloudy. \\
Scattered clouds. & Thunderstorms. Partly sunny. & More clouds than the sun. \\
Sunny. & Thundershowers. Partly sunny. & Drizzle. Fog. \\
Sprinkles. Partly cloudy. & Ice fog. & Light rain. Overcast. \\
Sprinkles. Broken clouds. & Overcast. & Drizzle. More clouds than the sun. \\
Thunderstorms. Broken clouds. & Sprinkles. & Drizzle. Mostly cloudy. \\
Sprinkles. Passing clouds. & Rain showers. Partly cloudy. & Thundershowers. Passing clouds. \\
Fog. & Rain showers. Fog. & Haze. \\
Light rain. Clear. & Rain. Overcast. & Sprinkles. Mostly cloudy. \\
Snow. Overcast. & Mostly cloudy. & Thundershowers. Partly cloudy. \\
Dense fog. & Snow flurries. Mostly cloudy. & Light rain. Cloudy. \\
Quite cool. & Rain. Cloudy. & Cloudy. \\
Light rain. Fog. & Rain. Scattered clouds. & Drizzle. Dense fog. \\
Rain. Partly sunny. & Low clouds. & Thundershowers. Broken clouds. \\
Mild. & Drizzle. Partly sunny. & \\
\hline & & \\
\hline
\end{tabular}

ii. Intervention: It is a dummy variable that coded as preintervention period and post-intervention period at time $\mathrm{t}$.

iii. y: Dependent variable as an outcome of the interventions at time $\mathrm{t}$.

We constructed an interrupted time series analysis model to measure electricity consumption's effect with the policy change intervention with these three variables. We also used the same independent variables with the multiple linear regression with the additional three variables, as shown in Eq. (1). The ITS model is shown below. Also, we added the interaction effect of the intervention variable and time elapsed variable.

The intersection factor is calculated as follows: $\beta_{\text {Interactioneffect }}=$ the coefficient of the interaction variable $X_{9} * X_{10}$

$$
\begin{aligned}
y=a+ & \beta_{\text {Temp }} X_{1}+\beta_{\text {wind }} X_{2}+\beta_{\text {Electricity price }} X_{3} \\
& +\beta_{\text {Intersection }} X_{4}+\beta_{\text {Humidity }} X_{5} \\
& +\beta_{\text {Weather }} X_{6}+\beta_{\text {Visibility }} X_{7}+\beta_{D S T} X_{8}+\beta_{\text {Time_elapsed }} X_{9} \\
& +\beta_{\text {intervention }} X_{10}+\beta_{\text {interaction effect }} X_{9} * X_{10}
\end{aligned}
$$

\subsection{Difference in differences method}

We also used DID in our study because it is another way to evaluate the effects of new policies. We observed outcomes of electricity consumption with clock change during the wintertime, which was exposed to the intervention and clock change in the 

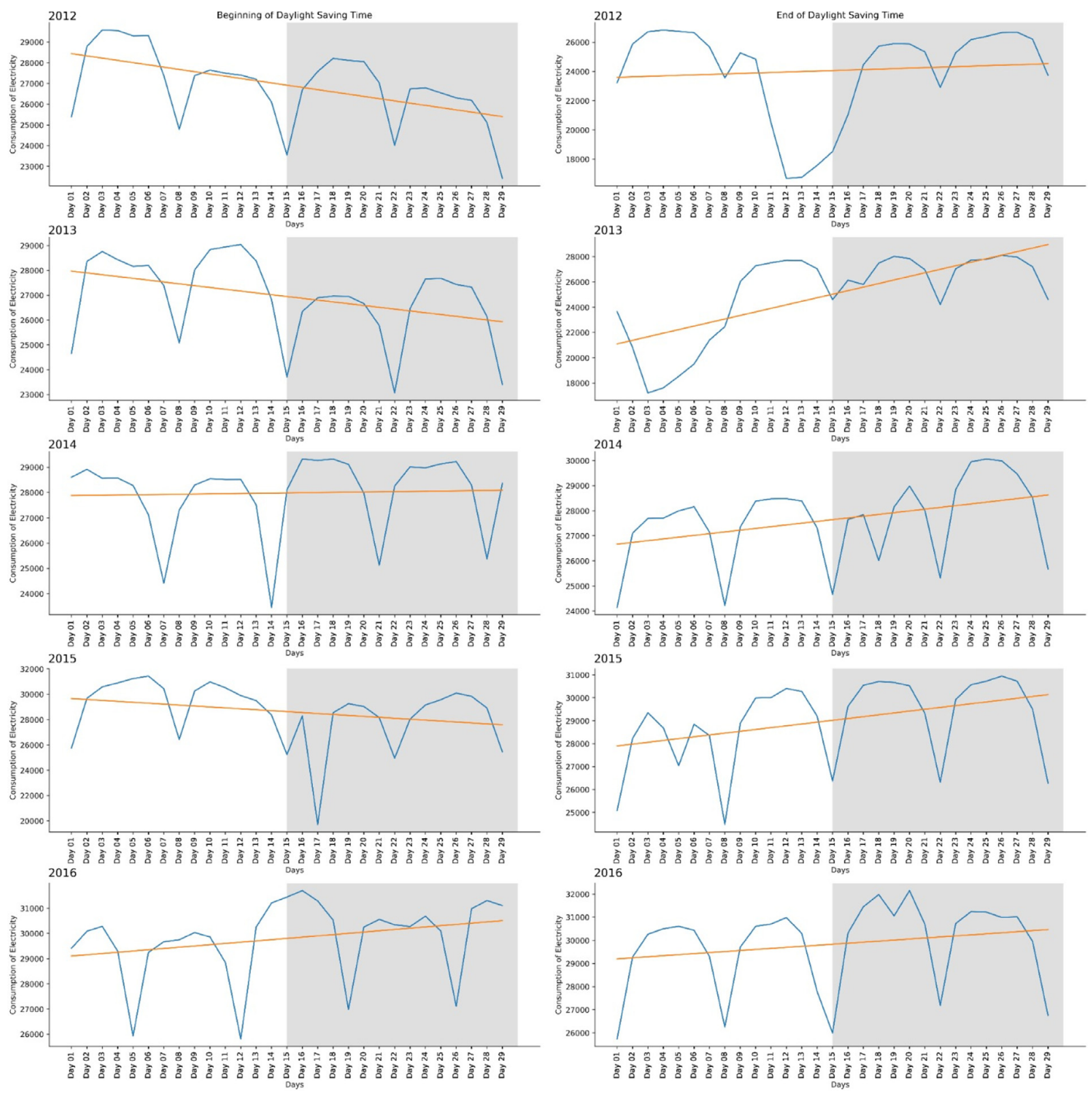

Fig. 1. Daily electricity consumption (MWh) during the months when clocks are changed.

summertime is defined as a control group. With the DST policy change in 2016, pre-intervention time and post-intervention time were defined. Post-2016 was defined as the post-intervention, and before 2016 was defined as the pre-intervention time. We also took account of the interaction of time and treatment. There is a representation of the model below.

$y=\beta_{\text {intervention }} X_{1}+\beta_{\text {treatment }} X_{2}+\beta_{\text {interaction }} X_{2} * X_{3}$

where,

$\mathrm{y}$ : dependent variable, which represents the electricity consumption.

$\aleph_{\text {intervention: }}$ the coefficient of the intervention factor and $X_{1}$ : the independent intervention variable,

$\beta_{\text {treatment }}$ : the coefficient of the DST and $X_{2}$ : independent treatment variable

$\aleph_{\text {intersection }}$ : the coefficient of the intersection factor, $X_{3}$ : independent time variable

\section{Results}

To measure the effect of DST on electricity consumption, we believe the intersection factor ( $\beta_{\text {Intersection }}$ ) plays a key role. Thus, we developed two scenarios that are related to working hours. Turkey's typical working hours start at $8 \mathrm{am}$ and ends at $5 \mathrm{pm}$ (public sector) or $6 \mathrm{pm}$ (private sector) in the evening. However, we should keep in mind that the workers need to wake up early to prepare for the day and make the necessary commute, especially in a crowded city like Istanbul. We define the working hour in the first scenario as 8:00-17:00 o'clock, which is the typical civil service work routine. However, we considered the preparation and commuting period for the second scenario and defined the working hour as 6:00-20:00 o'clock. We calculated the intersection of the daylight and working hours in two scenarios. Therefore, the only difference between the two scenarios is the intersection variables values.

Many parameters affect electricity consumption, and we only examined the meteorological variables and price of electricity. 

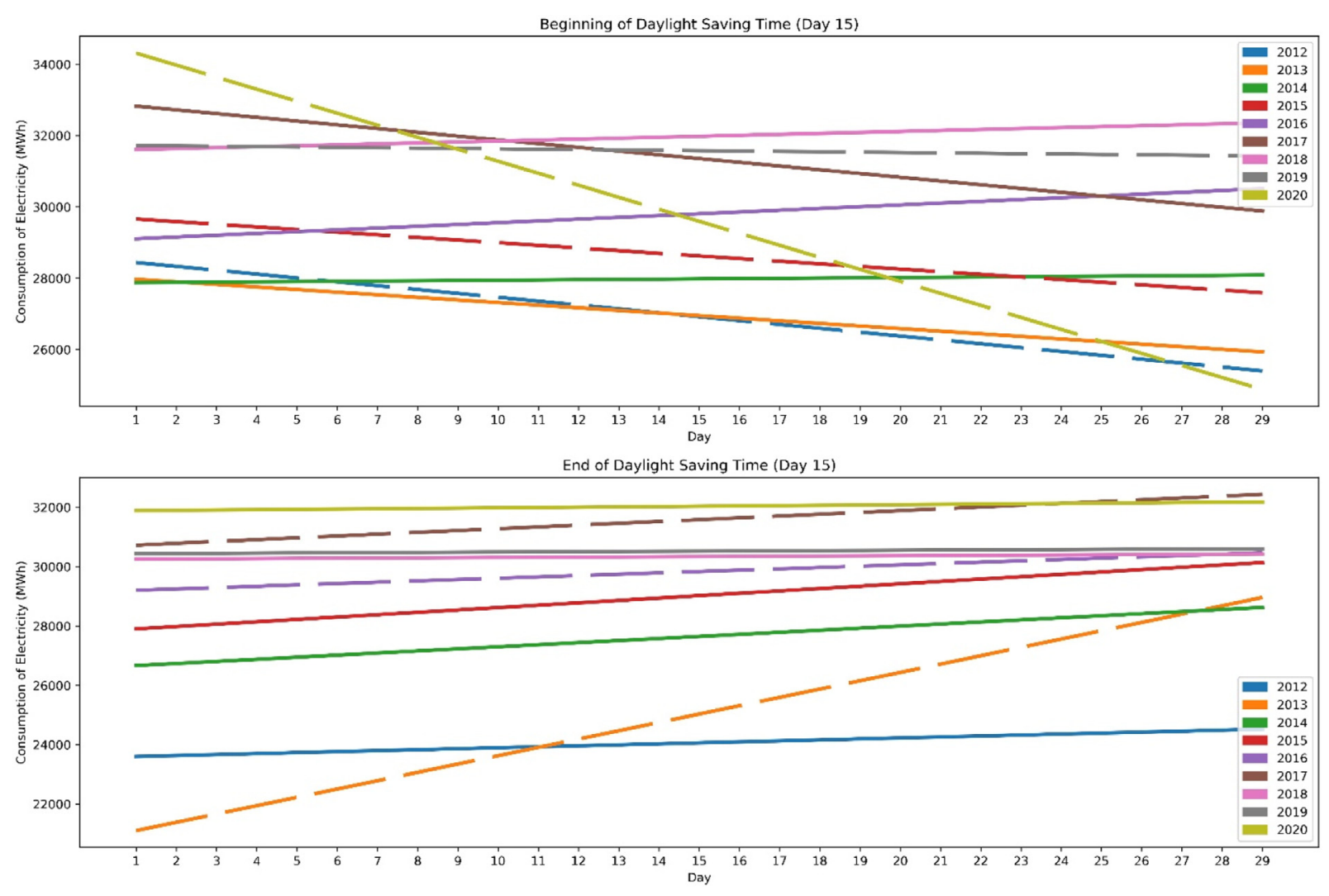

Fig. 2. Trendline of energy consumption between 2012-2020 before and after DST is applied.

Due to a lack of data, it is hard to take account of all of them. In Regression analysis, R-square and adjusted R-square results are generated. R-square is an indicator that shows the percentage of variation in the dependent variable, which is electricity consumption in our model. R-square is a tool to measure the overall goodness of fit of the model. The values range from 0 to 1 . An $\mathrm{R}$-square of 0 means that the explanatory variables explain none ( 0 per cent) of the variations of the dependent variable, whereas an R-square of 1 means that the explanatory variables explain the variation in the dependent variable perfectly (100 per cent).

For the multiple linear regression model, when we added a new independent variable to the model, the $\mathrm{R}$ square will be increased by its formula. Due to prevent that increase in R-square, we provided an adjusted R-square of all scenarios. Thus, the adjusted R-square provides the eliminate a spuriously increase in $\mathrm{R}$ square.

Table 5 shows the R-square and adjusted R-square results of our modelling without electricity price as a parameter, and Table 6 presents the same results with the electricity price parameter. On the other hand, For DID method, R-square result was found as 0.2017 .

R-square values show us the explainability of the dependent variable with independent variables. There is no specific R-square value that tells us that the dependent variable (in our case, the electricity consumption) is explained by the independent variables (in our case, the weather conditions and thus the DTS policy). However, in the literature, some claim that the R-square value higher than 0.90 provides an acceptable prediction for the dependent variable (Uyanık and Güler, 2013). In our case, we see that weather conditions, and thus DTS policy, fails to explain an observable impact on electricity consumption. When we add the electricity price as a parameter to the model, we see roughly a $20 \%$ increase in R-square values. However, it is still less than $50 \%$. If we add all the parameters that we listed in Table 2 to the regression models, the R-square will indeed approach $100 \%$. Atmospheric variables, and thus the DST policy-related parameters and energy prices, lead to an R-square value of a maximum of 0.5. To reach a complete analysis, we need to include all Social, Economic, Socio-economic, Socio-demographic, Appliances Variables, Character of Dwelling and Behavioural parameters into the calculation that we listed in Table 2. Nevertheless, it seems rather challenging to include all the relevant parameters in the analysis process as data acquisition will be highly difficult. Therefore, we can conclude that measuring the impact of only the DST policy on electricity consumption seems rather improbable. Fig. 1 shows the one-month energy consumptions and trends during the time change in the years when DST was applied.

Fig. 1 illustrates the electricity consumption for two weeks before and after the beginning and end of DST for the last five years (2012-2016) when Turkey decided to abolish DST in 2016. Coloured parts on the graphs represent the first two weeks after the time-zone change. According to these graphs, electricity consumption creates an almost weekly repetitive pattern by making a dip during the weekends and holidays. While there is no particular trendline pattern at the beginning of DST, a positively sloping trendline pattern is seen at the end of DST. This is understandable since, in autumn, heating naturally increases electric energy consumption in Turkey. During autumn 2016, Turkey did not enter the wintertime zone. However, we see a similar trend line with the previous years when the country changed clocks. When Turkey entered the summertime zones during springs, we see a decrease in electricity consumption (except for 2014 and 2016). However, we cannot claim that this was due to the DST policy since the warming weather means less heating, and the decreasing trend is observed weeks before the changing of the clocks dates. To compare the trend of electricity consumption with other years when DST was not applied, we depict Fig. 2, which shows one-month energy consumption trends during the 

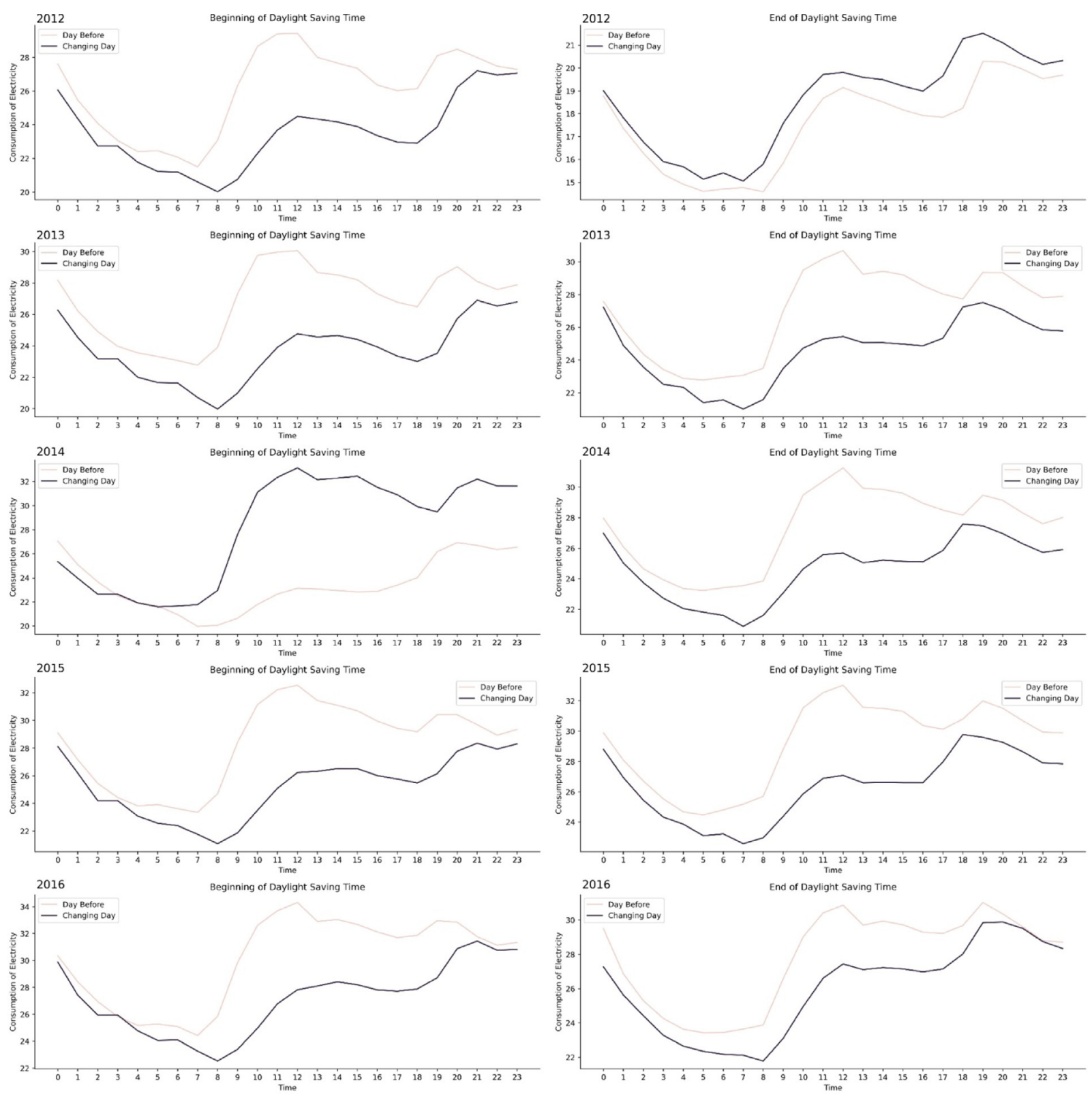

Fig. 3. Energy consumptions (GWh) of the time change day and the previous day.

Table 5

R-square results for MLR and ITS analysis without electricity price.

\begin{tabular}{llllll}
\hline Without electricity price & \multicolumn{2}{l}{ Multiple Linear Regression } & & \multicolumn{2}{l}{ Interrupted Time Series } \\
\cline { 2 - 3 } & $8.00-17.00$ Scenario & $6.00-20.00$ Scenario & & $8.00-17.00$ Scenario & $6.00-20.00$ Scenario \\
\hline R-Square & 0.3683 & 0.3662 & 0.3736 & 0.3727 \\
Adjusted R-Square & 0.3628 & 0.3607 & 0.3679 & 0.2017 \\
\hline
\end{tabular}

Table 6

R-square results for MLR and ITS analysis with electricity price.

\begin{tabular}{|c|c|c|c|c|}
\hline \multirow[t]{2}{*}{ With electricity price } & \multicolumn{2}{|c|}{ Multiple Linear Regression } & \multicolumn{2}{|c|}{ Interrupted Time Series } \\
\hline & $8.00-17.00$ Scenario & 6.00-20.00 Scenario & $8.00-17.00$ Scenario & 6.00-20.00 Scenario \\
\hline R-Square & 0.4401 & 0.44 & 0.4853 & 0.4835 \\
\hline Adjusted R-Square & 0.4352 & 0.435 & 0.4806 & 0.4787 \\
\hline
\end{tabular}

time change between 2012 and 2020, where day 15 designates the clock change date.

Fig. 2 further supports our argument that DST's impact on electricity consumption is neither observable nor measurable.
Whether or not DST is applied, there is a trend downwards during springs, and during autumn, the trend is upwards. In conclusion, we claim that we cannot measure DST's impact by observing R-square values, and we cannot follow the effect with trend lines. 

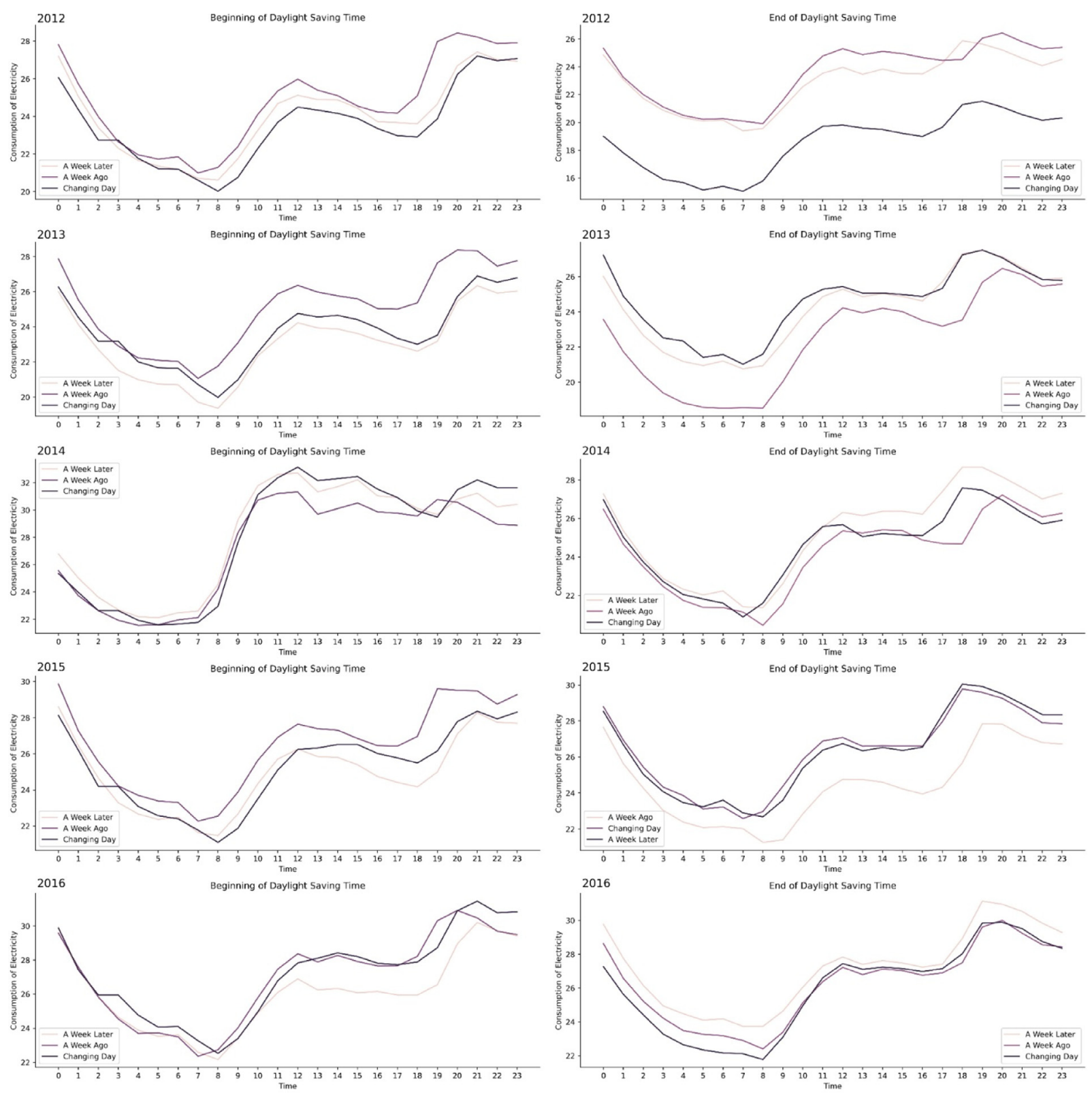

Fig. 4. Energy consumptions (GWh) of the time change day, the same day a week ago and the same day a week later.

This brings us to the next argument about the shift of energy consumption, or in other words, time-zone change results in a shift in the daily load curve of electricity. Some studies might claim that DST results in peak demand or peak load-shift in energy consumption $[4,13]$. To examine this claim, we depicted Fig. 3 to show daily load curves during and the day before the clock changes between 2012 and 2016.

When passing to the wintertime zone in autumns, we see only a one-hour load shift in Turkey in 2012. In the rest of the years, we observe no load shift. On the other hand, there are apparent one-hour load shifts in springs right after the DST. Nevertheless, we should highlight that in the clock change time at the beginning of daylight saving time, the empty time zone (3-4 am) is filled with the previous hour's value. Naturally, this will end up with a virtual load shift in the daily load curve. To investigate whether DST actually causes a load shift or not, we illustrated the daily load curves on the day of the clock change, a week ago and a week after the same day. Fig. 4 shows the daily load curves of these three days.
When we check the beginning of DST in springs between 2012 and 2016, we see a clear one-hour shift in the daily load curve (the dip generally shifts from 7 am to $8 \mathrm{am}$ ). However, we do not observe a consistent trend at the end of DST during autumns. Nonetheless, we should remind that the clock changes occur on the weekends, commonly on Sunday mornings. The energy consumption of the industry sector is minimal during weekends. Do we see a similar one-hour shift during weekdays when the working hours are fixed? To answer this question, we depicted Fig. 5 to show daily load curves on Mondays, one day after the clock change and one week before that Monday.

Fig. 5 shows a typical working day, Monday, behaviour before and after the clock change. We see no time shift in the daily load curve. This is understandable since the industry and service sector do not change their working hours before and after the DST. Therefore, we conclude that a one-hour load shift was only observed during weekends when we passed to the summertime zone, and it is not observed during autumns when the DTS is ended and during weekdays throughout the year. One other 

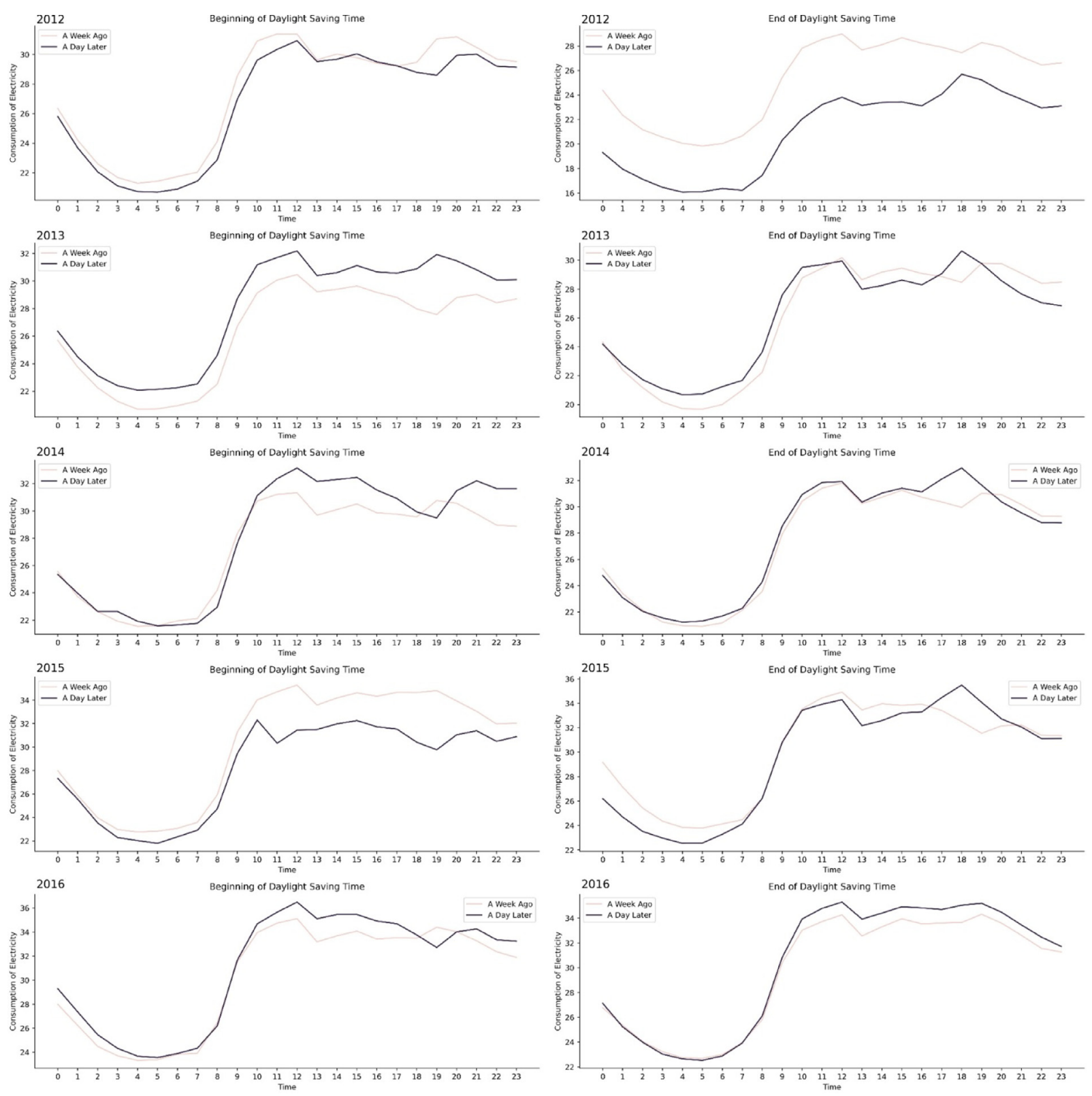

Fig. 5. Energy consumptions (GWh) of the one day after time change day and same day a week ago (on Mondays).

observation from Fig. 3 is that the energy consumption during the clock day's change is lower than the day before. To analyse whether the DST causes this or not, we depicted Fig. 6 to show random for weeks of daily load curves throughout a year.

Fig. 6 shows the hourly electricity consumption for four random weekends (2012-2016). DST is generally applied on Sunday mornings. That means the day before is Saturday. As can be seen from the graphs, there was more energy consumption on Saturdays than on Sundays. After illustrating the historical consumption data from Figs. 2 to 6, from the electrical engineering experiences, we might claim that DST cannot explain the decrease in energy consumption; instead, it can be explained by the people's behaviours and habits during Sundays.

\section{Discussion}

DST effect on energy consumption is primarily and predominantly seen in illumination (lighting) and heating. In this study, we made use of the total electricity consumption of Turkey rather than the residential load. One reason is that the country does not share hourly residential load data. We only had access to hourly overall energy consumption. The other reason is that the Ministry of Energy of Turkey claimed overall energy savings if the DST policy was to be abolished in 2016.

The studies underline that impact of DST on energy consumption depends on the climate, geographical properties and mathematical location (longitudes and altitudes) of the country or the region (Bellia et al., 2020; Bergland et al., 2017; Aries and Newsham, 2008). Moreover, the article Havranek et al. (2018) suggests that with increasing altitude, or as you go from the equator to the north and south poles, the energy savings will increase.

Our findings in this study may not apply to those countries with totally different latitudes, such as Northern Europe, Russia, or Canada. On the other hand, Turkey has similar mathematical location characteristics to Southern European countries, the United States, India and China. We believe that the MLR and ITS methodologies could be applied in other countries with similar 

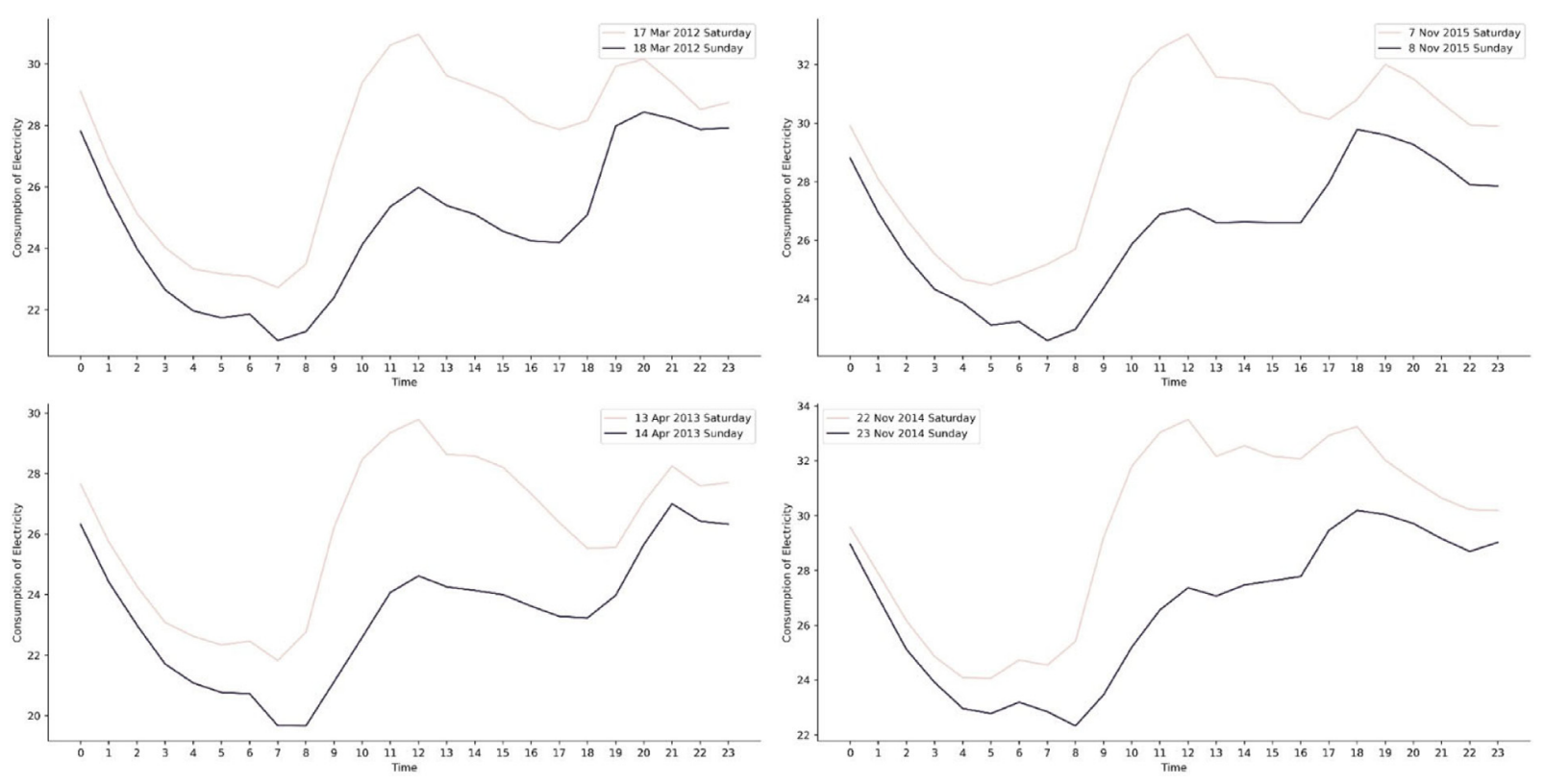

Fig. 6. Energy consumptions (GWh) of random four week's Saturdays and Sundays.

latitudes to Turkey. Turkey's latitude is $36^{\circ}-42^{\circ}$ north. To illustrate the idea, we draw a world map with blue lines on $42.0^{\circ}$ north and south of the equator (see Fig. 7).

Since we use essential climate variables in our models, we argue that our modelling must be applicable and reproducible for the countries in between $42.0^{\circ}$ north and $42.0^{\circ}$ south. One crucial observation is that the world's majority of the population and Gross Domestic Product (GDP) fall in this region. Therefore, we claim that for a majority of the population and GDP of the world, DST policy does not lead to any significant outcomes in terms of energy consumption. Of course, this claim needs to be proved by further similar studies to be conducted with the same methodology as we adopt here.

One other crucial matter is the reliability of the results. The studies claim that thanks to the decrease in lighting load, the energy consumption is decreased by $0.5 \%$ in the overall electricity consumption in the US (Aries and Newsham, 2008), 0.5\% in Slovakia (Kudela et al., 2020) and about 0.3\% in Great Britain (Hill et al., 2010). However, the US Energy Information Agency reports that only residential lighting load comprises only $1.7 \%$ of the total US electricity consumption in 2019 (U.S. Energy Information Administration (EIA), 2020). When we consider the share of residential lighting in total consumption, $1.7 \%$ in the US case, these saving estimations do not seem credible. We believe this observation further supports our claim that DST's impact on the total energy consumption is not measurable, meaning that it is not at a considerable level.

\section{Conclusions}

The impact of Daylight Saving Time (DST) on energy consumption has been a controversial matter for more than a century. Turkey repealed the DST policy in 2016 and decided to remain in the summertime zone claiming that the country would make significant energy savings. In this study, we applied two methodologies, Multiple Linear Regression (MLR) and Interrupted Time Series (ITS), to model the impact of Daylight Saving Time policy on electricity consumption. In the modelling, we made use of historical electric energy consumption, electricity prices and relevant atmospheric essential climate variables data in Turkey from 2012 to 2020 .
MLR and ITS are modelled with Eqs. (1) and (2), respectively. When we check Tables 4 and 5, ITS yields slightly higher Rsquared values, almost $1 \%$, more than MLR. The results indicate that including the electricity prices as an input to the analysis increases the R-squared values almost by $20 \%$. However, the overall figures, which are less than $50 \%$, falls below the expected threshold, which is $90 \%$, for a reliable and acceptable conclusion. On the other hand, Figs. 1 and 2 shows the trend lines of energy consumption two weeks before and after the clock change dates. From these figures, we cannot observe that there is an energysaving, or a decrease in consumption, due to the DST policy. Therefore, we argue that switching time zones does not have a measurable or observable impact on energy savings.

One other crucial finding was about a possible one-hour load shift due to the DST. Indeed, Figs. 3-5 show us that there is a one-hour load shift during the springs' weekends. However, there is no load shift during weekends of autumn and the weekdays throughout the year. Therefore, we claim that the argument for the one-hour load shift due to the DST is quite limited and cannot be observed continually.

To sum up, there are dozens, or perhaps hundreds, of parameters that affect energy consumption. Using historical datasets in Turkey in two different methodologies, we conclude that timezone switching neither increases nor decreases energy consumption at a measurable amount. Furthermore, the one-hour load shift is not observable throughout the year. Saving energy by time zone switching needs further evidence and clarification.

\section{CRediT authorship contribution statement}

Sinan Küfeoğlu: Conceptualization, Methodology, Writing. Şahincan Üçler: Data curation, Formal analysis, Writing. Furkan Eskicioğlu: Visualisation, Investigation. E. Büssra Öztürk: Visualisation, Investigation. Hao Chen: Validation.

\section{Declaration of competing interest}

The authors declare that they have no known competing financial interests or personal relationships that could have appeared to influence the work reported in this paper. 


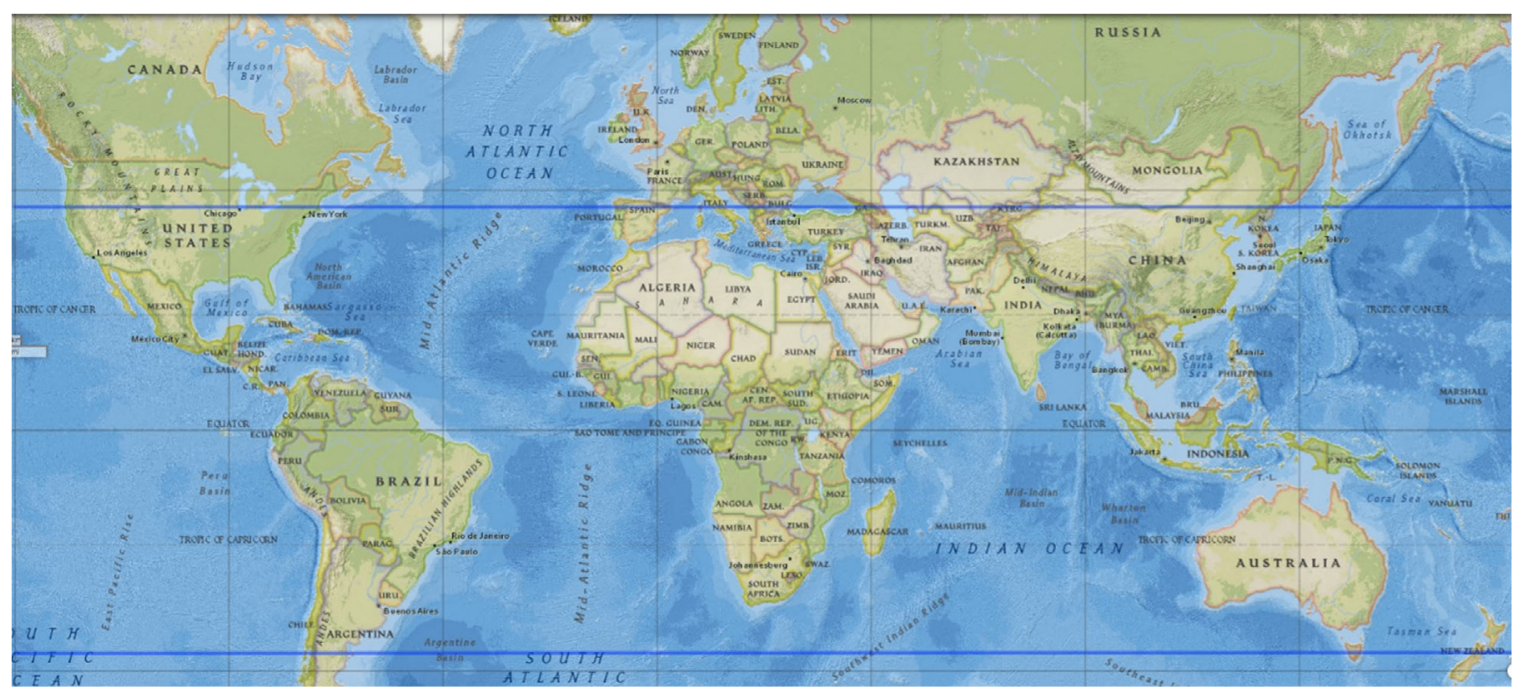

Fig. 7. $42.0^{\circ}$ north and south of the equator.

\section{Acknowledgments}

This research work is completed as a part of TUBITAK 2232 International Outstanding Research Fellowship programme with the funding from project grant no 118C370.

\section{Appendix A. Supplementary data}

Supplementary material related to this article can be found online at https://doi.org/10.1016/j.egyr.2021.08.025.

\section{References}

Abanda, F.H., Byers, L., 2016. An investigation of the impact of building orientation on energy consumption in a domestic building using emerging BIM (Building Information Modelling). Energy 97, 517-527. http://dx.doi.org/10. 1016/j.energy.2015.12.135.

Amber, K.P., et al., 2019. Effect of different factors on the electricity consumption and electricity usage intensity (EUI) of residential buildings in Pakistan. Rev. Constr. 17 (3), 473-483. http://dx.doi.org/10.7764/RDLC.17.3.473.

Aries, M.B.C., Newsham, G.R., 2008. Effect of daylight saving time on lighting energy use: A literature review. Energy Policy 36 (6), 1858-1866. http: //dx.doi.org/10.1016/j.enpol.2007.05.021.

Awad Momani, M., Yatim, B., Ali, M.A.M., 2009. The impact of the daylight saving time on electricity consumption-A case study from Jordan. Energy Policy 37 (5), 2042-2051. http://dx.doi.org/10.1016/j.enpol.2009.02.009.

Baker, K.J., Rylatt, R.M., 2008. Improving the prediction of UK domestic energydemand using annual consumption-data. Appl. Energy 85 (6), 475-482. http://dx.doi.org/10.1016/j.apenergy.2007.09.004.

Bellia, L., et al., 2020. Impact of daylight saving time on lighting energy consumption and on the biological clock for occupants in office buildings. Sol. Energy 211, 1347-1364. http://dx.doi.org/10.1016/j.solener.2020.10.072.

Belzer, D.B., Hadley, S.W., Chin, S.-M., 2008. Impact of extended daylight saving time on national energy consumption report to congress. http://dx.doi.org/ $10.2172 / 949762$.

Bergland, O., et al., 2017. Latitudinal effect on energy savings from daylight savings time. Available at: https://econpapers.repec.org/RePEc:hhs:nlsseb: 2017_008. (Accessed 29 January 2021).

Çalmaşur, G., Inan, K., 2018. Hanehalkı Elektrik Talebini Etkileyen Faktörler: Türkiye Üzerine Bir Uygulama. Erciyes Üniv. İktisadi İdari Bilimler Fakültesi Derg. (52), 71-92. http://dx.doi.org/10.18070/erciyesiibd.435627.

Chen, Y.T., 2017. The factors affecting electricity consumption and the consumption characteristics in the residential sector-a case example of Taiwan. Sustainability (Switzerland) 9 (8), http://dx.doi.org/10.3390/su9081484.

Cihat, A., Korkmaz, O., 2009. Türkiye Kisa Süreli Elektrik Talebinin Saatlik Olarak Tahmin Edilmesi.

Druckman, A., Jackson, T., 2008. Household energy consumption in the UK: A highly geographically and socio-economically disaggregated model. Energy Policy 36 (8), 3177-3192. http://dx.doi.org/10.1016/j.enpol.2008.03.021.

Erdogan, R.T., et al., 2016. Karar Sayısı: 2016/9154 Yönetmelik Adı-7. Available at: https://www.resmigazete.gov.tr/eskiler/2016/09/20160908-2. pdf. (Accessed 18 March 2021).
Ewusie, J.E., et al., 2020. Methods, applications and challenges in the analysis of interrupted time series data: A scoping review. J. Multidiscip. Healthc. http://dx.doi.org/10.2147/JMDH.S241085.

Gatama, M.N., 2014. Factors influencing household energy consumption: the case of biomass fuels in Kikuyu District of Kiambu County, Kenya. Doctoral dissertation. University of Nairobi.

Ghedamsi, R., et al., 2016. Modeling and forecasting energy consumption for residential buildings in Algeria using bottom-up approach. Energy Build. 121, 309-317. http://dx.doi.org/10.1016/j.enbuild.2015.12.030.

Guan, H., et al., 2017. Incorporating residual temperature and specific humidity in predicting weather-dependent warm-season electricity consumption. Environ. Res. Lett. 12 (2), 024021. http://dx.doi.org/10.1088/1748-9326/ aа57a9.

Haliloğlu, E.Y., Tutu, Y., 2018. TÜRKIYYE İÇiN KISA VADELİ ELEKTRIKK ENERJiSİ TALEP TAHMINI SHORT-TERM ELECTRICITY POWER DEMAND FORECASTING FOR TURKEY. J. Yasar Univ. Available at: https://dergipark.org.tr/en/pub/ jyasar/285007. (Accessed 16 January 2021).

Hancevic, P., Margulis, D., 2016. Daylight saving time and energy consumption: The case of Argentina.

Havranek, T., Herman, D., Irsova, Z., 2018. Does daylight saving save electricity? A meta-analysis. Energy J. 39 (2), 63-86. http://dx.doi.org/10.5547/01956574. 39.2.thav.

Hill, S.I., et al., 2010. The impact on energy consumption of daylight saving clock changes. Energy Policy 38 (9), 4955-4965. http://dx.doi.org/10.1016/j.enpol. 2010.03.079.

Huebner, G., et al., 2016. Understanding electricity consumption: A comparative contribution of building factors, socio-demographics, appliances, behaviours and attitudes. Appl. Energy 177, 692-702. http://dx.doi.org/10. 1016/j.apenergy.2016.04.075.

Jones, R.V., Fuertes, A., Lomas, K.J., 2015. The socio-economic, dwelling and appliance related factors affecting electricity consumption in domestic buildings. Renew. Sustain. Energy Rev. 901-917. http://dx.doi.org/10.1016/j.rser.2014. 11.084.

Karasu, Servet, 2010. Yaz Saati Uygulamasinin Binalarda Aydinlatma İçin Kullanilan Elektrik Tüketimine Etkileri. in. İstanbul. Available at: https://www.researchgate.net/publication/308903648_YAZ_SAATI_ UYGULAMASININ_BINALARDA_AYDINLATMA_ICIN_KULLANILAN_ELEKTRIK_ TUKETIMINE_ETKILERI. (Accessed 29 January 2021).

Kavousian, A., Rajagopal, R., Fischer, M., 2013. Determinants of residential electricity consumption: Using smart meter data to examine the effect of climate, building characteristics, appliance stock, and occupants' behavior. Energy 55, 184-194. http://dx.doi.org/10.1016/j.energy.2013.03.086.

Kellogg, R., Wolff, H., 2008. Daylight time and energy: Evidence from an Australian experiment. J. Environ. Econ. Manage. 56 (3), 207-220. http: //dx.doi.org/10.1016/j.jeem.2008.02.003.

Kim, M.J., 2018. Characteristics and determinants by electricity consumption level of households in Korea. Energy Rep. 4, 70-76. http://dx.doi.org/10.1016/ j.egyr.2017.12.001.

Kotchen, M.J., Grant, L.E., 2011. Does daylight saving time save energy? Evidence from a natural experiment in indiana. Rev. Econ. Stat. http://dx.doi.org/10. 1162/REST_a_00131.

Krarti, M., Hajiah, A., 2011. Analysis of impact of daylight time savings on energy use of buildings in Kuwait. Energy Policy 39 (5), 2319-2329. http: //dx.doi.org/10.1016/j.enpol.2011.01.046. 
Kudela, P., et al., 2020. Does daylight saving time save electricity? Evidence from Slovakia. Energy Policy 137. http://dx.doi.org/10.1016/j.enpol.2019.111146.

Kuehnle, D., Wunder, C., 2016. Using the life satisfaction approach to value daylight savings time transitions: Evidence from britain and germany. J. Happiness Stud. 17 (6), 2293-2323. http://dx.doi.org/10.1007/s10902-0159695-8.

López, M., 2020. Daylight effect on the electricity demand in Spain and assessment of Daylight Saving Time policies. Energy Policy 140, 111419. http://dx.doi.org/10.1016/j.enpol.2020.111419.

Lopez Bernal, J., Cummins, S., Gasparrini, A., 2017. Interrupted time series regression for the evaluation of public health interventions: a tutorial. Int. J. Epidemiol. 46 (1), 348-355. http://dx.doi.org/10.1093/ije/dyw098.

MGM, 2021. Meteorolojik Veri-Bilgi Sunum ve Satış Sistemi. [Çevrimiçi] Available at: https://www.mgm.gov.tr/site/urunler.aspx?u=tum. (Accessed 6 April 2021).

Mirza, F.M., Bergland, O., 2011. The impact of daylight saving time on electricity consumption: Evidence from southern Norway and Sweden. Energy Policy 39 (6), 3558-3571. http://dx.doi.org/10.1016/j.enpol.2011.03.057.

Prerau, D.S., 2005. Seize the Daylight: The Curious and Contentious Story of Daylight Saving Time. Thunder's Mouth Press.

Priva, U.C., Sanker, C., 2019. Limitations of difference-in-difference for measuring convergence. Lab. Phonol. 10 (1), http://dx.doi.org/10.5334/labphon.200.

Rock, B.A., 1997. Impact of daylight saving time on residential energy consumption and cost. Energy Build. 25 (1), 63-68. http://dx.doi.org/10.1016/s03787788(96)00990-5.

Sakai, M., Mihoko, 2013. The effect of economic factors and energy efficiency programs on residential electricity consumption, PhDT. Available at: https: //ui.adsabs.harvard.edu/abs/2013PhDT........59S/abstract. (Accessed 16 January 2021).

Sexton, A.L., Beatty, T.K.M., 2014. Behavioral responses to daylight savings time. J. Econ. Behav. Organ. 107 (PA), 290-307. http://dx.doi.org/10.1016/j.jebo.2014. 03.012 .

Shabunko, V., et al., 2014. Developing building benchmarking for Brunei Darussalam. Energy Build. 85, 79-85. http://dx.doi.org/10.1016/j.enbuild.2014.08. 047.
Shrestha, P.P., Kulkarni, P., 2010. Identifying factors that affect the energy consumption of residential buildings. In: Construction Research Congress 2010. American Society of Civil Engineers, Reston, VA, pp. 1437-1446. http: //dx.doi.org/10.1061/41109(373)144.

State of the Union, 2018. Q\&A on the Commission's proposal to put an end to seasonal clock changes. Available at: https://ec.europa.eu/commission/ presscorner/detail/en/MEMO_18_5641. (Accessed 26 January 2021).

TEIASS, 2021. YTBS. [Çevrimiçi] Available at: https://ytbsbilgi.teias.gov.tr/ytbsbilgi/ frm_istatistikler.jsf. (Accessed 6 April 2021).

The World Clock - Worldwide, 2021. Available at: https://www.timeanddate. com/worldclock/. (Accessed 16 January 2021).

Tso, G.K.F., Yau, K.K.W., 2003. A study of domestic energy usage patterns in Hong Kong. Energy 28 (15), 1671-1682. http://dx.doi.org/10.1016/S03605442(03)00153-1.

U.S. Energy Information Administration (EIA), 2020. Available at: https://www. eia.gov/tools/faqs/faq.php?id=99\&t=3. (Accessed 26 January 2021).

Uyanık, G.K., Güler, N., 2013. A study on multiple linear regression analysis. Procedia - Soc. Behav. Sci. 106, 234-240. http://dx.doi.org/10.1016/j.sbspro. 2013.12.027.

Verdejo, H., et al., 2016. Impact of daylight saving time on the Chilean residential consumption. Energy Policy 88, 456-464. http://dx.doi.org/10.1016/j.enpol. 2015.10.051.

Weedmark, D., 2018. The advantages \& disadvantages of a multiple regression model, Sciencing. Available at: https://sciencing.com/advantagesdisadvantages-multiple-regression-model-12070171.html. (Accessed 16 January 2021).

Zaharia, A., et al., 2019. Factors influencing energy consumption in the context of sustainable development. Sustainability 11 (15), 4147. http://dx.doi.org/ $10.3390 /$ su11154147.

Zhou, H., et al., 2016. Difference-in-differences method in comparative effectiveness research: Utility with unbalanced groups. Appl. Health Econ. Health Policy 14 (4), http://dx.doi.org/10.1007/s40258-016-0249-y. 